\title{
有明海における陸域負荷の長期変動の推定 および赤潮発生に及ぼす流入水量の影響 \\ ESTIMATE OF LONG-TERM VARIATION OF INFLOW LOADS, AND THE EFFECT OF INFLOW DISCHARGE ON RED TIDE IN THE ARIAKE SEA
}

\author{
手塚公裕 1 ・大串浩一郎 2 - 緒方直人 3 \\ Masahiro TEZUKA, Koichiro OHGUSHI and Naoto OGATA \\ 1正会員 博士（工学） 佐賀大学低平地沿岸海域研究センター（广840-8502 佐賀市本庄町1番地）

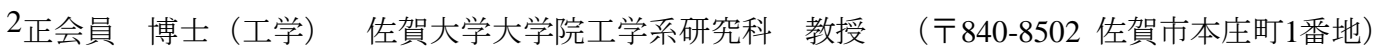 \\ 3 学生会員 佐賀大学理工学部都市工学科（下840-8502 佐賀市本庄町1番地）
}

\begin{abstract}
It is necessary to grasp a long term inflow load for the study of enclosed bay. The Ariake Sea is one of such bay and there are some missing data of river discharge flowing into this bay. In this study, our developed method to estimate the missing discharge data is applied to all major rivers flowing into this bay. Amounts of inflow loads are calculated using L-Q curves and pollutant load factors. Long term changes of the river discharges and loads into the bay are estimated from 1981 to 2010 . A characteristic of inflow discharge's change and a relationship between red tide occurrences and the inflow discharges are also discussed. The inflow discharge and loads of COD, T-N and T-P are found not to be changing in the Ariake Sea from 1981 to 2010. An increase of the inflow discharge is considered to be a trigger for a red tide occurrence not in winter but in the season between spring to autumn in the Ariake Sea.
\end{abstract}

Key Words: Ariake Sea, inflow river discharge, inflow loads, long-term variation, red tide

\section{1. はじめに}

有明海では，1980年代に漁獲量の減少が始まり，2000 年12月に生じた大規模赤潮に伴うノリの不作をきっかけ に環境異変が注目された。2002年には「有明海及び八代 海を再生するための特別措置に関する法律」が施行され, その後, 環境異変の原因解明と対策が進められてきた. しかし，明らかにされていない問題は未だに数多くあり， その最大の原因は過去のデータの不足と考えられる.

閉鎖性の強い有明海は陸域の影響を強く受ける. 従っ て海洋環境変化の原因を解明するためには陸域負荷の長 期変動を把握する必要がある。 しかし，1981～2010年に おける有明海流入一級河川の順流域末端地点で時刻流量 データに久測がない年は 2008 年のみであり, データの久 測が陸域負荷を推定する際の障害となっている.

環境省有明海・八代海総合調查評価委員会の報告書1) では，1965２001年の年流入負荷量の一部が算定されて いる. また，朴ら ${ }^{2)}$ は，有明海流入河川流域の分布型流 出モデルを構築し, 土地利用等の環境変化が流出量に与 える影響を考察している. しかし，これらの報告では幾 つかの代表年のみが対象であり長期的変動の検討が不十
分である，一方，秋季における降雨は，流入負荷を増大 させ赤潮を誘発すると考えられている 負荷と赤潮の長期変動や流入水量と赤潮発生時期の関係 については明らかにされていない.

以上のことより，本研究では，過去30年間（1981〜 2010年）の有明海流入河川流量データの久測を補間し, 流入水量の長期変動を推定すると共に流入水量の変動特 性および流入水量と赤潮発生の関係について検討した.

\section{2. 流入水量 ·負荷量のデータセットの構築}

\section{（1）流域区分}

本研究における有明海流域のブロック区分（図-1）は, 有明海水域に係る下水道整備総合計画に関する基本方針 策定調查報告書 (有明流総) ${ }^{4)}$ をべースとし, 全一級河 川および塩田川（二級河川であるが面積が大きい）を順 流域と感潮域に区分し，その他を直接流入域とした。 ま た，直接流入域は県界と流域界で区分した。有明流総で は六角川水系牛津川と緑川水系加勢川の順流域が感潮域 に区分されていたが，本研究ではGIS解析により順流域 と感潮域に区分した。 さらに，有明海に流入する区域毎 
にブロックをまとめ, 西部，東部，奥部に区分した.

\section{（2）有明海に流入する水量と負荷量の推定方法}

流入水量と各負荷量は以下の方法で算出した

\section{a）順流域の河川流量}

順流域最下流の観測所の時刻流量データ（1981～2010

年）を収集し，データに欠測がある場合は，図-3に示す 欠測流量データの補間方法5)に従って補間した.

久測流量の補間に用いたタンクモデルパラメータの同 定は，RMSE(Root Mean Square Error)が小さくなるよう にSCE-UA(Shuffled Complex Evolution) ${ }^{6}$ ) を用いて探索し, 局所解に陥ったと判断された場合は個別にチューニング した．同定には，欠測を補間する年に近く欠測のない年 のデータを用いた．計算流量と欠測補間をする年に存在 する実測流量を比較して誤差が大きい場合や前後の年と 不連続な場合，流出率が近隣流域と著しく異なる場合等 は再度チューニングを行った．既往の検討 ${ }^{5)}$ を参考にし， タンクモデルは直列4段とした。流域平均雨量はティー セン法，蒸発散量はソーンスウェイト法で算出した。

流量観測所の時刻流量データを整備した後，各流量観 測所の比流量を求めた. 比流量に順流域面積を乗じるこ とで，各順流域の河川流量を算出した。六角川と塩田川 では流量観測が行われていなかったため, 牛津川の比流 量を各ブロックの面積に乗じて両河川の流量を求めた.

河川流量のデータセット構築過程でデータエラーに関 する問題が生じた．特に深刻な問題は，観測所と時間が 同じで流量が異なるものである。これはデータベース作 成時の転記ミスや，水位と流量の関係式の更新による流 量データの変更等が原因と考えられた。これらのデータ は，前後の年との連続性，雨量との関係等から妥当と判 断されるものを採用した。また，久測がないデータで あっても明らかな不連続性がみられるケースもあった。 例えば，1年間の連続データが前後の年と不連続で, ベースも常に高く，明らかに他の観測所のデータと推測 されるケース, $0 \mathrm{~m}^{3} \cdot \mathrm{s}^{-1}$ のデータが不連続に生じ自動水位

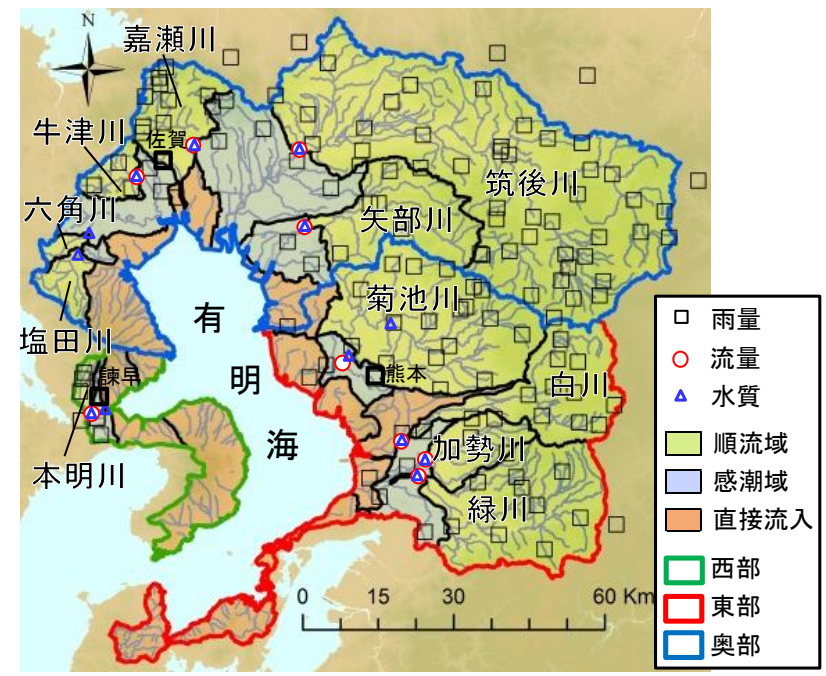

図-1＼cjkstart有明海流域の観測点とブロック区分
観測計のトラブルがあったと推測されるケースがあった。 これらは明らかなエラ一值と判断し，久測として扱った。

b）順流域の負荷量

順流域最下流の観測所の水質データ（1981～2010年） を収集し，流量と負荷量の関係式（L-Q式）を作成した。 有明流総 ${ }^{4)}$ ではL-Q式を3段階に分類し，定期調査を[平 常時], 洪水時調査を[洪水時]に区分し，間を[中間時]と していた.しかし，この分類は流量と負荷量の関係を基 にしたものではなく，3つのL-Q式は不自然に結合され ていた，本研究では，収集した定期調査と洪水時調査の 全データを用い，観測所毎に[平常時]と[洪水時]のL-Q式 を作成した. 分類基準流量を段階的に変化させ，相関係 数が高くなるL-Q式を探索した。その結果，全河川で $0.1 \mathrm{~m}^{3} \cdot \mathrm{km}^{-2} \cdot \mathrm{s}^{-1}$ 付近に変化点がみられたため, 分類基準 に用いる比流量とした。

L-Q式の作成過程でもデータエラーに関する問題が生 じた． 観測所と時間が同じで水質データが異なることが あった. エラーはT-N, T-Pで確認されたため, 異なる 分析方法（総量を一括して定量する方法，形態別で定量 した後に合算する方法等）の結果が記載されていた可能 性がある. 本研究では無機態栄養塩とのバランスを考慮 し，妥当と考えられる水質データを採用した.

\section{c）感潮域と直接流入域の河川流量}

感潮域と直接流入域の河川流量は，近隣順流域の比流 量に各ブロック面積を乗じて算出した.

\section{d）感潮域と直接流入域の負荷量}

点源負荷は，有明流総 $\left.{ }^{4}\right) の$ 流域フレーム（1995，2000, 2005，2010年）と原単位を用い，これらを乗じて算出し た. 有明流総で取り扱っていない年は，ブロック毎に線 形補間を行った。面源負荷は，国土数值情報の土地利用

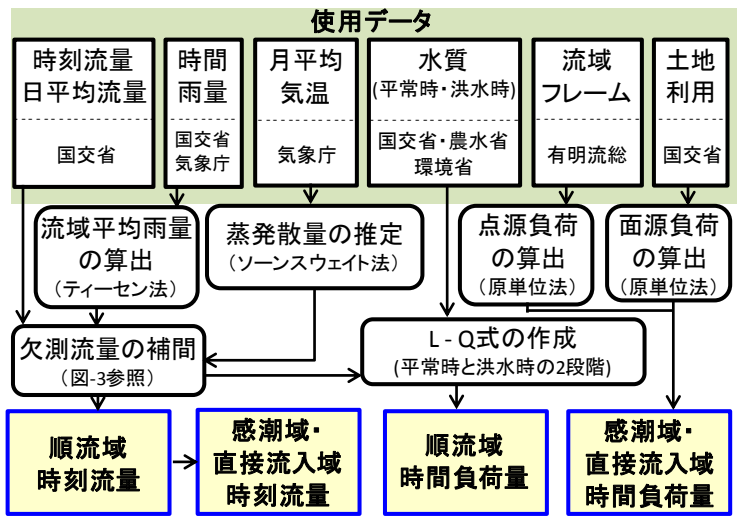

図-2 流入水量・負荷量の算定方法

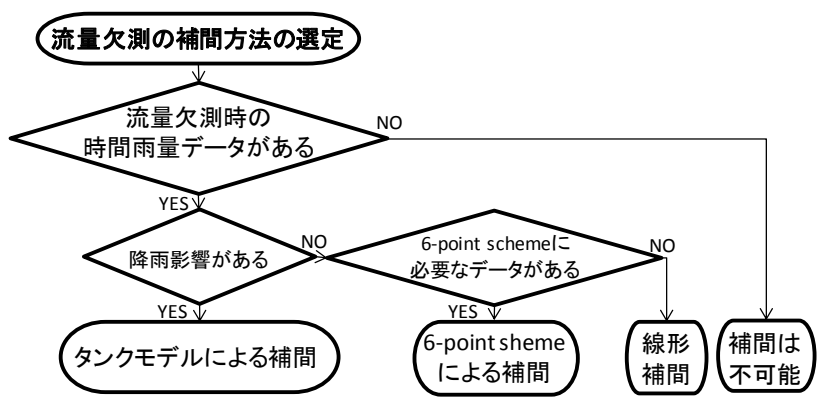

図-3欠測流量データの補間方法 
データ（1976，1987，1991，1996，2006年）から各ブ ロックの土地利用種別面積を算出し，有明流総の原単位 を乗じて求めた（図-4）。土地利用データのない年は, ブロック毎に線形補間を行った。感潮域と直接流入域の 各ブロックの負荷量は，点源負荷と面源負荷の和とした．

\section{3. 結果と考察}

（1）流入水量 · 負荷量の経年変化

1981～2010年の有明海における降水量, 流入水量,
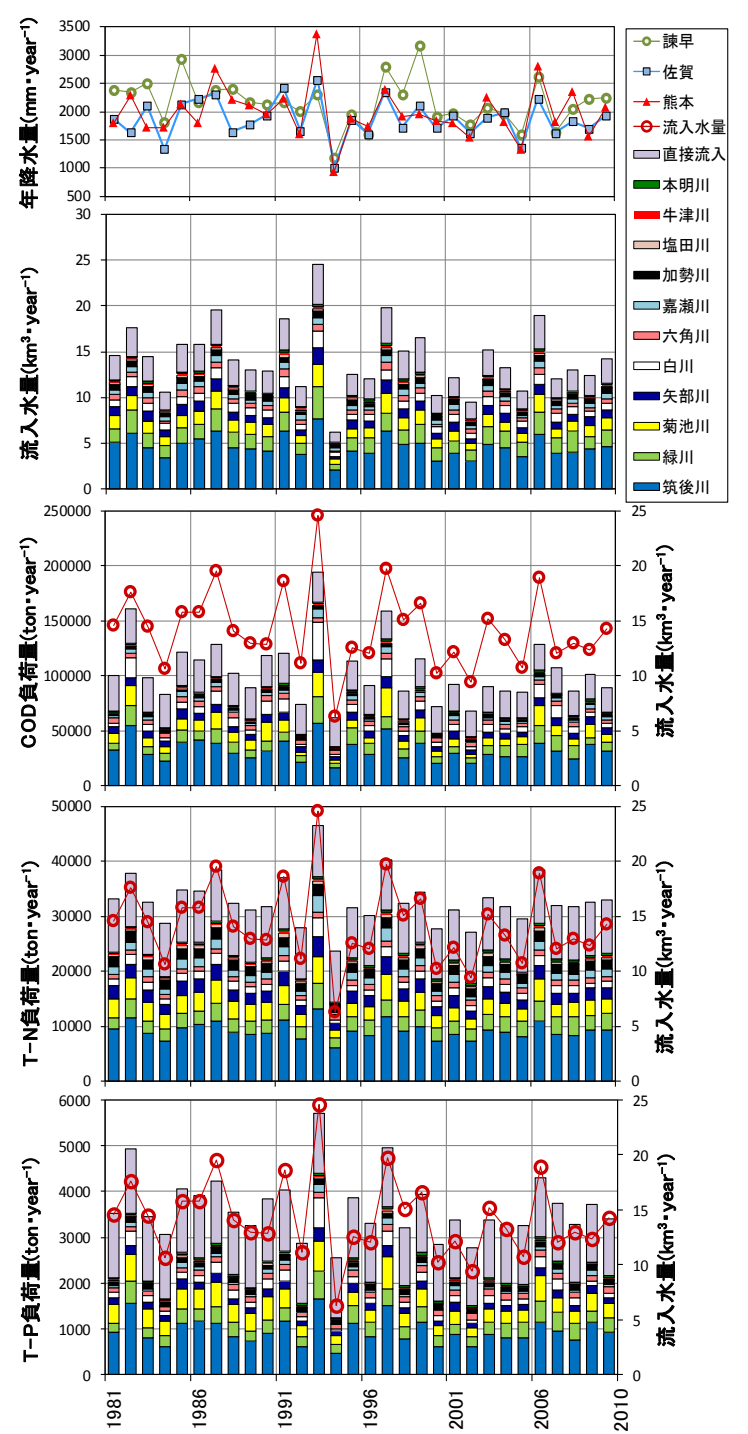

図-5 降水量, 流入水量, 各負荷量の経年变化
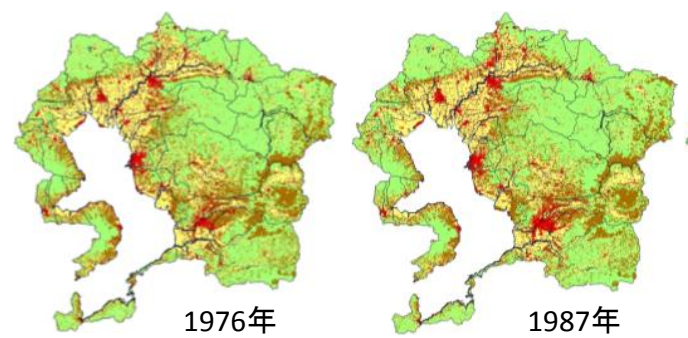

1987年
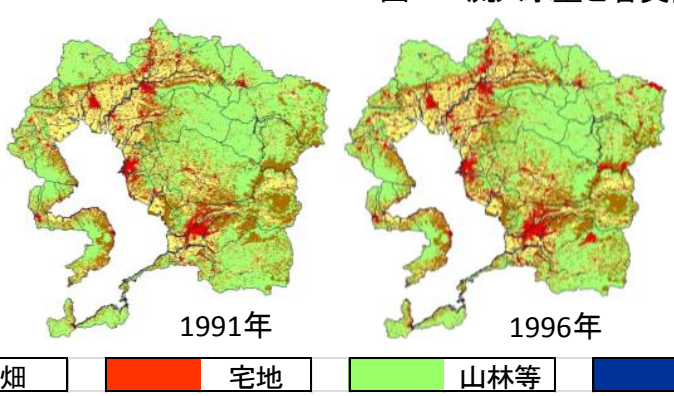

山林等
COD，T-N，T-P負荷量は，概ね同様の経年変化を示し た（図-5）。流入水量と各負荷量は降水量の変動に伴い 変化しており，1993年に最大值，1994年に最小值を示し た. 本研究の結果と環境省が推定した年（1981～1985, 1990，1993～1995，1998～2001）の報告值 ${ }^{1}$ を比較した 結果，差の平均はCODで約12\%，T-Nで約4\%，T-Pで約 10\%であった. これは推定に用いたデータ（土地利用， 水質等）やブロック区分の相違が原因と考えられる.

1981～1990年，1991～2000年，2001～2010年の3期間 の全ての組み合わせ（3パターン）でF検定と $\mathrm{t}$ 検定を 行った結果, 流入水量, COD, T-N, T-P負荷量の全項 目，全組み合わせで有意差がなかった（ $\mathrm{p}>0.05 ）$. 環境 省の報告書 ${ }^{11)}$ では断続的に各負荷量を推定して，昭和50 年代以降は減少傾向にあると記述しているが，経年的な 各負荷量の変化はないと考える方が妥当である.

有明海流域の約 3 割を占める筑後川流域は，全期間平 均で流入水量, 各負荷量の約 3 割を占めていた。一方, 有明海流域の約 2 割を占める直接流入域は，全期間平均 で流入水量の約 2 割， COD，T-N負荷量の約 3 割，T-P負 荷量の約4割を占めており, 排出される負荷量は筑後川 と同等以上であることが明らかとなった．流域面積の割 合よりも負荷量の割合が多くなっていたのは，直接流入 域には市街地が分布しており, 人為的負荷が多いことが 原因と考えられる.

各年の流入水量と各負荷量の相関を図-6に示寸．流入 水量と各負荷量の相関係数は0.85以上であり, 強い正の 相関がみられた．1981～2010年の期間においては，流入 水量と負荷量の関係に及ぼす流域の土地利用や水利用の 変化等の人為的影響が軽微であったと考えられる．そこ で，本論では流入水量に着目して考察を進める.

\section{（2）ブロック別比流量の経年変化}

ブロック別の年平均比流量の経年変化を図-7に示す.

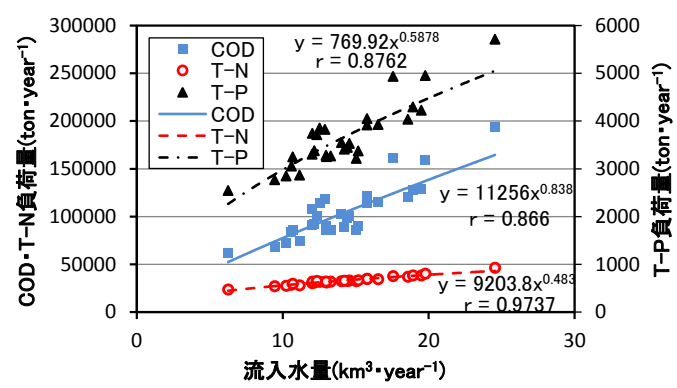

図-6 流入水量と各負荷量の相関

図-4 有明海流域の土地利用の変遷 
緑川水系加勢川順流域の比流量が他ブロックに比べて常 に高い值を示した。このブロックには，1日約 40 万 $\mathrm{m}^{3} の$

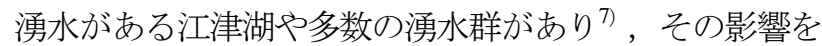
受けたものと考えられる。一方，矢部川流域，㐘池川流 域は他の地域よりも低い傾向がみられた。これらの流域 は山林が多く，土地利用の影響を受けている可能性が示 唆される. 1999年の西部では他ブロックよりも高い值を 示した.この年の7月には豪雨（梅雨）があり，本明川 流域では多数の洪水被害が生じている。 このように，ブ ロック別の比流量の平面分布を時系列で俯瞰することで, 有明海流域の特性の理解を進めることが可能となった.

\section{（3）流入水量の経月変化}

有明海に流入する地域別（西部・東部・奥部）の流入 水量および全流入水量に占める各地域の割合の経月変化 を図-8に示す．1981～2010年の平均流入水量の割合は， 流域面積の割合とほぼ同じで，奥部（約55\%），東部 （約38\%），西部（約7\%）の順で多かった。また，全 流入水量に占める各地域の割合には，奥部と東部に周期 性がみられた，奥部では冬季に低く，夏季に高い傾向が あり，東部では逆の傾向があった．流域面積は奥部より 東部で小さいが, 冬季の降水量と流入水量は奥部と東部 で同程度であった．従って，この周期性は降雨の流出率 もしくは湧水量の相違が影響していると推測される.

1988年と2010年の年間流入水量は約 $14 \mathrm{~km}^{3} \cdot \mathrm{year}^{-1}$ と同 程度であったが，ピークが現れる月は1988年では6月， 2010年では7月と異なった．また，年間流入水量の最大
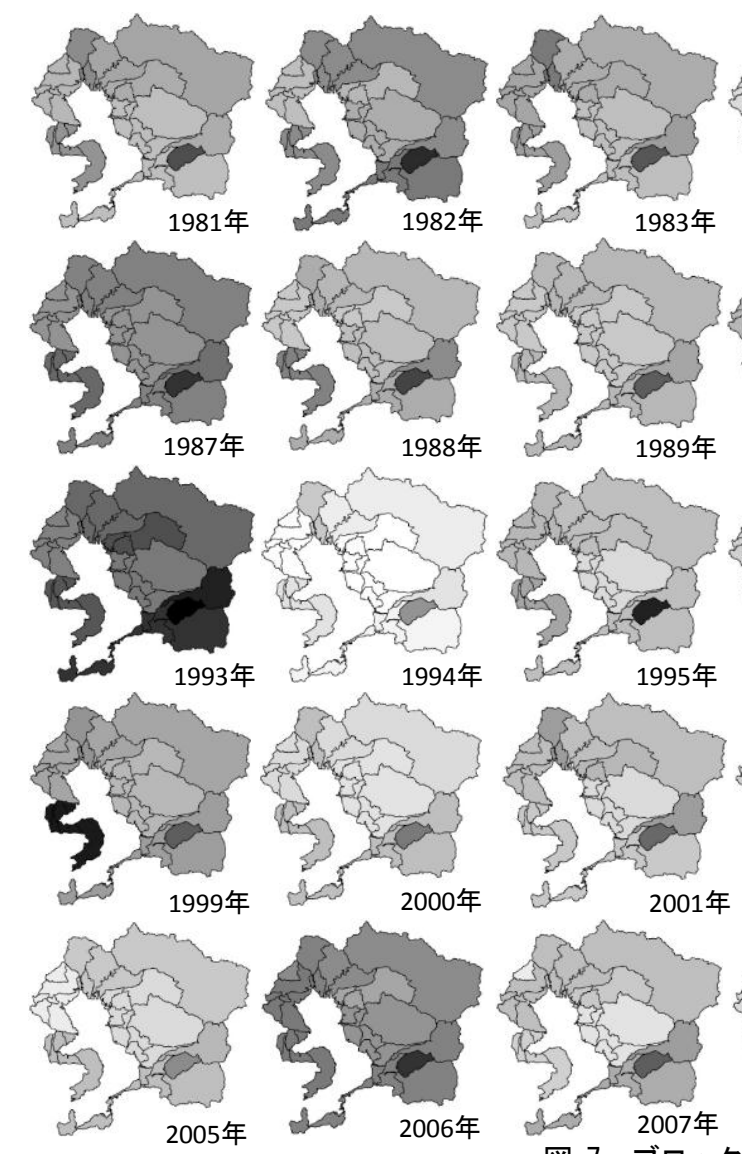

值は1993年であったが，月間流入水量の最大值は 1982 年7月にあり，ピークが異なった。このように月単位に データを細分化することで年単位では分からなかった流 入水量の変動特性を把握することができる.

\section{（4）全流入水量の季節変動特性の分類}

流入水量の経月変化から年間流入水量が同程度であっ ても流入するパターンが年により異なる可能性が考えら れた．そこで，1981２010年の年毎の全流入水量の月 データをクラスター分析により類型化し, 流入水量の特 性を調べた. その結果, 全流入水量は5つのクラスター に分類できることが明らかとなった（図-9）．各クラス ターのデータを平均化し, クラスターの特徵を明確にし た（図-10）．各クラスターの流入水量の経月変化は次 のような特徴があった. クラスターAは7月にピークが あり量は平均的, クラスターBは7月にピークがあり量 が多い, クラスターCは7月にピークがあり, 量が多く,

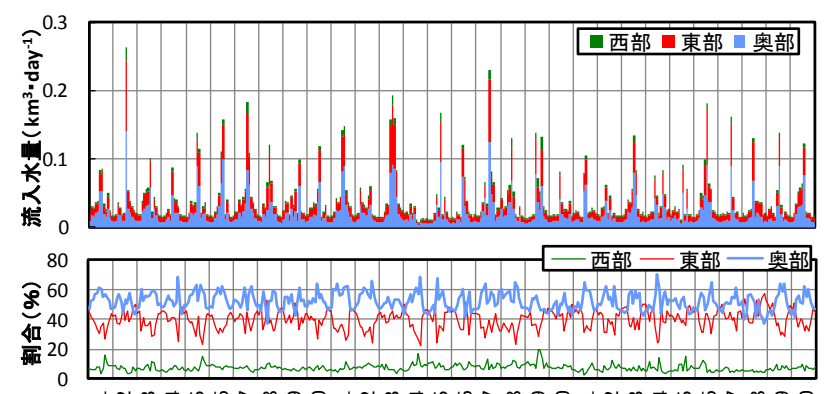

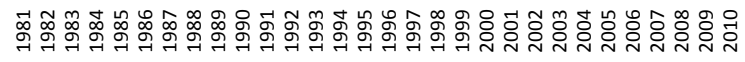
図-8 流入地域別の流入水量の経月変化
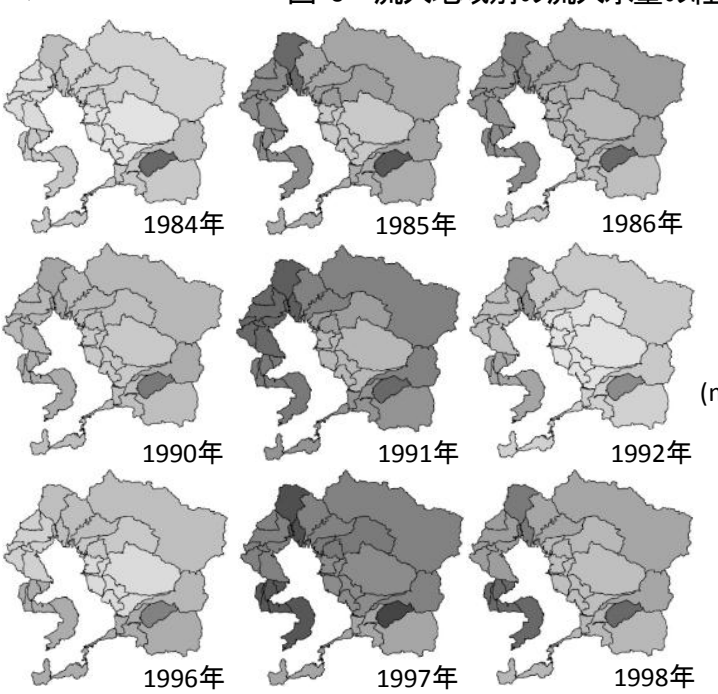

比流量

$\left(\mathrm{m}^{3} \cdot \mathrm{km}^{-2} \cdot \mathrm{day}^{-1}\right)$
$\tau^{11400}$
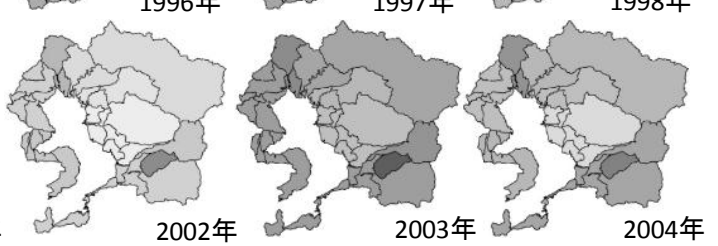

$-10000$

$-7500$
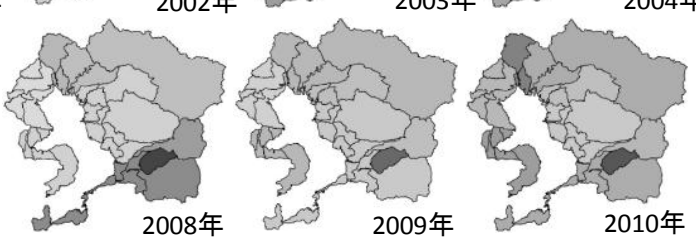

図-7 ブロック別の年平均比流量の経年変化 
6月と8月も多め, クラスターDは6月にピークがあり量 は平均的，クラスターEは通年で量が少ない，という特 徴であった。

1981～2010年における各クラスターの発生頻度は，A が10回，Bが6回，Cが1回，Dが7回，Eが6回であり，発 生に周期性やトレンドはなかった。 これは流入水量の変 動が，流域の土地利用や水利用の変遷に伴う経年的な降 雨流出率の変化よりも, 年による降水量の相違に起因し ていることを示唆している.

\section{（5）有明海における流入水量と赤潮の関係}

有明海における流入水量と赤潮（最大細胞数・最大面 積）の時系列変化を図-11に示す. 図中の最大細胞数と 最大面積は各赤潮が発生していた全期間にプロットして いる. また，クラスター分析により分類した流入水量の

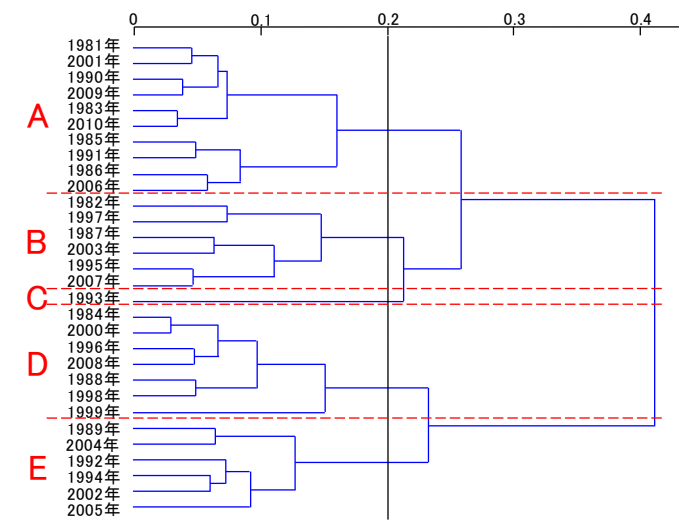

図-9 クラスター分析による全流入水量の分類
パターンも付記し，赤潮との関係を検討した. なお，赤 潮データは水産庁九州漁業調整事務所の資料（九州海域 の赤潮）を用いた。ただし，2004年以降は最大面積の不 明な赤潮が多いことに留意する必要がある.

春季から秋季にかけて発生する赤潮は，大部分が降雨 出水の数日以内に生じ, 流入水量に応じて赤潮の最大細 胞数と最大面積が大きくなる傾向がみられた。 これは流 入水量が多い時には栄養塩の供給が増えるためである （図-6）。しかし，その傾向に合致しないケースもあっ た.クラスターC（2003年）では，流入水量が特に多い が，最大細胞数と最大面積は他のクラスターよりも低 かった。 これは滞留時間の低下が原因と考えられる。ま た，流入水量の少ないクラスターEであっても，赤潮が 他のクラスターと同様に発生することがあった．従って， 流入水量の増加は赤潮発生のトリガーとなるが，赤潮の 発生規模は海洋構造, 日射量, 赤潮の構成種, 捕食者等 の影響を受けるものと考えられる. 一方，冬季の赤潮は, 他の時期とは異なり, 流入水量の増加していない場合で も発生するケースが多くみられた。

春季～秋季（4～10月） と冬季（11～3月）における流 入水量と赤潮発生規模指標の関係を図-12に示す。流入

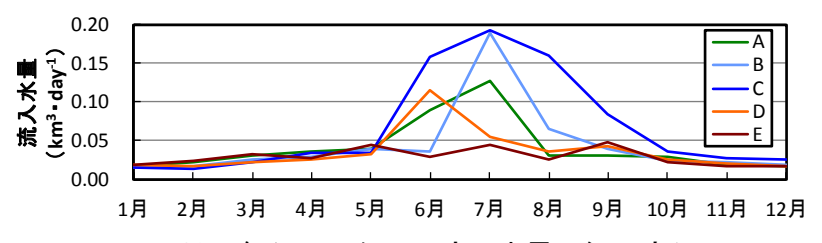

図-10 各クラスターの流入水量の経月変化

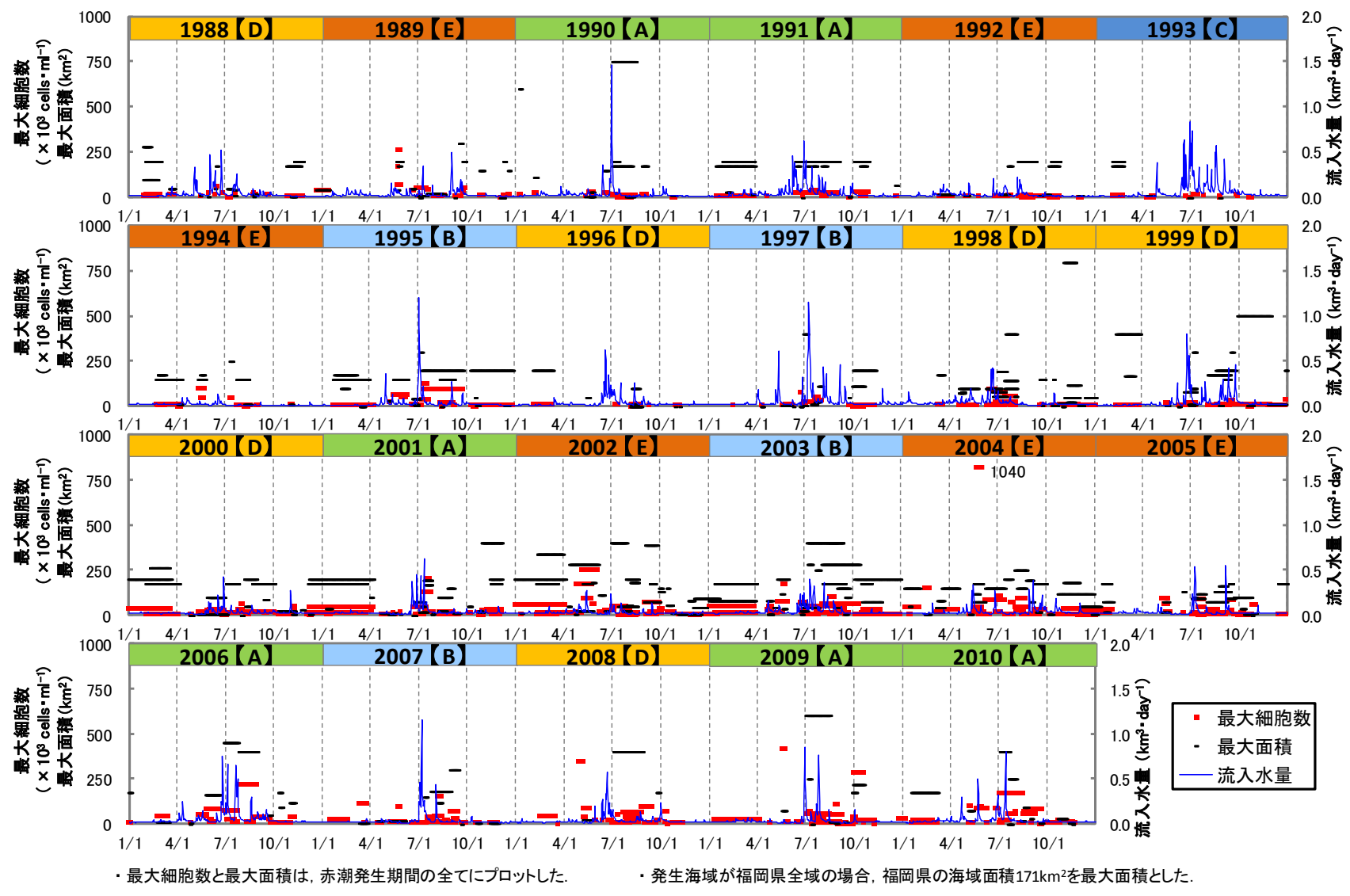

図-11 有明海における流入水量と赤潮（最大細胞数 - 最大面積）の時系列変化 
水量と赤潮発生規模指標は, 堤らの研究3) を参考とした. 流入水量は赤潮発生前 40 日間の合計水量とし，赤潮発生 規模指標は赤潮の最大面積と発生期間の積とした．春季 〜秋季の赤潮は，赤潮発生前 40 日間の流入水量 $0.4 \sim$ $8 \mathrm{~km}^{3}$ の範囲で生じていた。 また， $0.4 \sim 5 \mathrm{~km}^{3}$ の範囲では 流入水量が多いほど赤潮発生規模指標の最大值が大きく なる傾向がみられ，最大で35,000程度に達した。一方， 冬季の赤潮は $0.4 \sim 2 \mathrm{~km}^{3}$ の範囲で赤潮が発生していた. 冬季の流入水量は少ないが，赤潮発生規模指標が 10,000 を超える大規模な赤潮が多数あった. 赤潮発生規模指標 を同一流入水量時（流入水量 $0.5 \sim 1.0 \mathrm{~km}^{3}$ ) の平均值で 比較すると, 春季〜秋季（約 $1,200 ）$ よりも冬季（約 3,900）で有意に高かった（p<0.01）。これらのことか ら冬季の赤潮は流入水量以外の要因で発生し, 春季〜秋 季の赤潮とは発生メカニズムが異なると推測される.

冬季における赤潮は流入水以外からの栄養塩の供給を 受けて発生していると推測される。一般に, 底質からの 栄養塩溶出は温度の低い冬季では少ないため, 陸域と底 質以外からの栄養塩の供給源が考えられる．林ら ${ }^{8)}$ は, 秋季から春季にかけてのノリ養殖に用いる酸処理剤が赤 潮を誘発している可能性を指摘している. しかし，ノリ 養殖時に有明海に投入される酸処理剂中の栄養塩量は赤 潮の発生に影響しないとの見解もある ${ }^{9}$. 冬季の赤潮に 関する研究は少なく, 有明海の環境異変を解明する上で 重要な課題と考えられる.

流入水量別の赤潮発生規模指標の経年変化を図-13に 示す．なお，久測の多い2004年以降のデータは除外した。 流入水量と赤潮発生規模指標の関係に経年変化はみられ なかった. 一方，赤潮発生規模指標之発生回数は段階的 な増加傾向があり，有明海の赤潮は1990～1991年頃に一 度目の大規模化が生じ，1997～1999年頃に二度目の大規 模化が起きたと考えられる．堤ら゙) は，1990～2001年の 秋季のデータを解析し, 諫早湾潮受け堤防の影響を受け 1998年以降に赤潮が大規模化したと指摘している. この 赤潮の大規模化は本研究で示した二度目の大規模化にあ たる. 潮受け堤防締め切り以前に生じた一度目の赤潮の 大規模化は，これまで把握されていなかった現象であり， 今後その原因の解明が必要である.

\section{4. 結論}

本研究で得られた結論を以下に示寸.

（1） 1981～2010年の有明海への流入水量, COD, T-N, T-P負荷量の連続データを推定した結果，全項目で

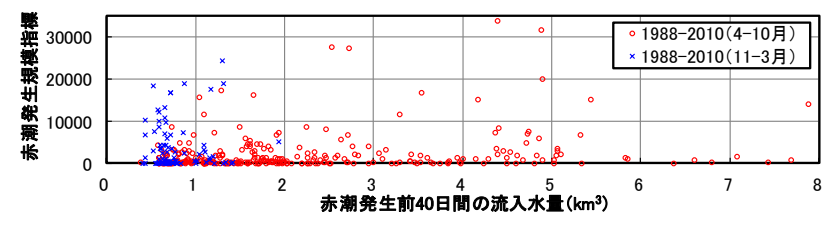

図-12 時期別の流入水量と赤潮発生規模指標の関係
経年的な変化がないと考えられた．また，直接流入 域の負荷量が他流域よりも多いことが分かった.

（2）流入水量の時空間分布から，有明海の流域特性が明 らかとなった. また，クラスター分析により全流入 水量を5つのクラスターに分類することができた.

（3）春季〜秋季の流入水量の増加は赤潮発生のトリガー となることが分かった. 一方, 冬季の赤潮は流入水 量の影響を受けないことが明らかとなった。 また， 有明海の赤潮は，1990～1991年頃に一度目の大規模 化が生じ，1997〜1999年頃に二度目の大規模化が起 きたと考えられた.

謝辞 : 本研究は, 平成 24 年度笹川科学研究助成および科 研費基盤研究（A）（21246078，代表者：松永信博）の 助成を受けたものである. デー夕を頂いた国土交通省, 農林水産省, 環境省, 気象庁, データ整理にご協力頂い た佐賀大学流域水工学研究室の皆様に謝意を表します.

\section{参考文献}

1) 環境省有明海・八代海総合調查評価委員会:委員会報告, 2006 .

2) 朴童津ほか: 有明海の全流域における環境変化が流出量に与 える影響の評価, 水工学論文集, Vol.53, pp.481-486, 2009.

3) 堤裕昭ほか: 有明海奥部海域における近年の貧酸素水塊およ び赤潮発生と海洋構造の関係, 海の研究, Vol.12(3), pp.291305, 2003.

4) 九州地方整備局:有明海水域に係る下水道整備総合計画に関 する基本方針策定調査報告書, 2005.

5) M.Tezuka, K. Ohgushi: A practical method to estimate missing discharge data, IAHR-APD, pp.547-548, 2012.

6) Duan, Q., Sorooshian, S. and Gupta, V.K.: Effective and effient global optimization for conceptual rainfall-runoff models, Water Resource Research, Vol.28, No.4, pp.10151031, 1992.

7) 九州地方整備局: 緑川水系河川整備計画(原案】, 2011.

8) 林重徳ほか:有明海湾奥部における干潟環境再生のための地 盤工学的視点からの取組み, 環境地盤工学シンポジウム発表 論文集, Vol.7, pp.1-10, 2007.

9) 日本海洋学会編:有明海の生態系再生をめざして, pp.164-165, 恒星社厚生閣, 2005.

(2012. 9. 30受付)

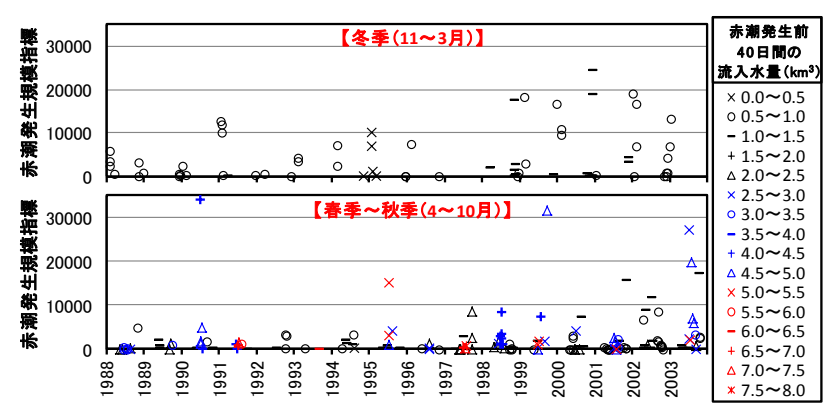

図-13 流入水量別の赤潮発生規模指標の経年変化 